\title{
Axitinib versus sorafenib in advanced renal cell carcinoma: subanalyses by prior therapy from a randomised phase III trial
}


G Kannourakis ${ }^{9}$, M Staehler ${ }^{10}$, J Tarazi ${ }^{11}$, B Rosbrook ${ }^{11}$, L Cisar ${ }^{12}$, S Hariharan ${ }^{12}$, S Kim ${ }^{11,14}$ and B I Rini ${ }^{13}$ ${ }^{1}$ Institut Gustave Roussy/Medical Oncology Department, Villejuif 94805, France; ${ }^{2}$ Department of Medicine, Massachusetts General Hospital Cancer Center, Boston, MA 02114, USA; ${ }^{3}$ Department of Medicine, Memorial Sloan-Kettering Cancer Center, New York, NY 10021, USA; ${ }^{4}$ Baylor-Sammons/Texas Oncology Physician's Association, Sammons Cancer Center, Dallas, TX 75246, USA; ${ }^{5}$ Department of Medicine, Loyola University Chicago Cardinal Bernardin Cancer Center, Maywood, IL 60153, USA; ${ }^{6}$ Department of Internal Medicine, Samsung Medical Center/Sungkyunkwan University, Seoul 135-710, Korea; 'Queen Elizabeth Hospital Birmingham, Birmingham B15 2WB, UK; ${ }^{8}$ Durham Regional Cancer Centre, Oshawa, Ontario L1G 2B9, Canada; ${ }^{9}$ Fiona Elsey Cancer Research Institute and Ballarat Oncology and Haematology Services, Ballarat, Victoria 3355, Australia; ${ }^{10}$ Ludwig-Maximilians University of Munich, Munich 80539, Germany; ${ }^{11}$ Pfizer Oncology, San Diego, CA 92121, USA; ${ }^{12}$ Pfizer Oncology, New York, NY 10017, USA and ${ }^{13}$ Department of Solid Tumor Oncology, Cleveland Clinic Taussig Cancer Institute, Cleveland, OH 44195, USA

Background: In the AXIS trial, axitinib prolonged progression-free survival (PFS) vs sorafenib in patients with advanced renal cell carcinoma (RCC) previously treated with sunitinib or cytokines.

Methods: In post hoc analyses, patients were grouped by objective response to prior therapy (yes vs no), prior therapy duration ( $<v s \geqslant$ median), and tumour burden (baseline sum of the longest diameter $<$ vs $\geqslant$ median). PFS and overall survival (OS), and safety by type and duration of prior therapy were evaluated.

Results: Response to prior therapy did not influence outcome with second-line axitinib or sorafenib. PFS was significantly longer in axitinib-treated patients who received longer prior cytokine treatment and sorafenib-treated patients with smaller tumour burden following sunitinib. Overall survival with the second-line therapy was longer in patients who received longer duration of prior therapy, although not significant in the sunitinib-to-axitinib sequence subgroup; OS was also longer in patients with smaller tumour burden, but not significant in the cytokine-to-axitinib sequence subgroup. Safety profiles differed modestly by type and duration of prior therapy.

Conclusions: AXIS data suggest that longer duration of the first-line therapy generally yields better outcome with the second-line therapy and that lack of response to first-line therapy does not preclude positive clinical outcomes with a second-line vascular endothelial growth factor-targeted agent in patients with advanced RCC.

Over the past decade, the introduction of targeted agents has transformed the treatment paradigm for metastatic renal cell carcinoma (mRCC). Targeted agents currently approved for use in mRCC inhibit either the vascular endothelial growth factor
(VEGF) pathway or the mammalian target of rapamycin (mTOR) pathway (National Comprehensive Cancer Network, 2013). As targeted therapies are rarely curative and often result in resistance or intolerance, sequential regimens of these agents are commonly

\footnotetext{
${ }^{\star}$ Correspondence: Dr B Escudier; E-mail: escudier@igr.fr

${ }^{14}$ Employed at Pfizer Inc at the time of the study described here.
}

Received 10 February 2014; revised 7 April 2014; accepted 10 April 2014; published online 13 May 2014 
used (Hudes et al, 2011) and are recommended in current treatment guidelines (Escudier et al, 2012; Ljungberg et al, 2013; National Comprehensive Cancer Network, 2013). However, data from prospective clinical trials evaluating different drug sequences are limited.

The AXIS trial was the first randomised phase III study to compare two active VEGF-targeted agents, axitinib and sorafenib, for second-line treatment of mRCC (Rini et al, 2011; Motzer et al, 2013b). Compared with sorafenib, axitinib significantly improved progression-free survival (PFS) in the overall trial population as well as in the subgroups of patients previously treated with sunitinib or cytokines (Rini et al, 2011). In an updated analysis (Motzer et al, 2013b), median investigator-assessed PFS continued to be longer with axitinib compared with sorafenib in patients previously treated with sunitinib or cytokines, although median overall survival (OS) was similar between second-line treatment arms.

We conducted post hoc analyses of the AXIS trial to evaluate the efficacy of axitinib and sorafenib by response to prior therapy, duration of prior therapy, and tumour burden in patients previously treated with sunitinib or cytokines. Safety and treatment exposure by type and duration of prior therapy were also explored.

\section{PATIENTS AND METHODS}

Study design and treatment. This multicentre, open-label, randomised, phase III trial was conducted to compare the safety and efficacy of axitinib $v s$ sorafenib in patients with mRCC who had failed one prior systemic therapy. As previously described (Rini et al, 2011), eligible patients had advanced RCC with clear cell histology, measureable disease per Response Evaluation Criteria in Solid Tumours (RECIST v1.0) (Therasse et al, 2000), Eastern Cooperative Oncology Group (ECOG) performance status 0 or 1 , and progressive disease after one prior sunitinib-, bevacizumab plus interferon-alfa-, temsirolimus-, or cytokinecontaining regimen.

Patients were stratified by ECOG performance status and prior therapy and randomised $1: 1$ to receive either axitinib at a starting dose of $5 \mathrm{mg}$ twice daily (b.i.d.) or sorafenib at a starting dose of $400 \mathrm{mg}$ b.i.d. Dose increases of axitinib based on individual tolerability and reductions or interruptions of axitinib and sorafenib for toxicities were previously described (Rini et al, 2011; Motzer et al, 2013b).

The trial was conducted in accordance with the Declaration of Helsinki, the International Conference on Harmonisation Guidelines on Good Clinical Practice, and applicable local regulatory requirements and laws. All patients provided written informed consent. The protocol, amendments, and informed consent forms were approved by an institutional review board or independent ethics committee at each study site. The trial is registered on ClinicalTrials.gov (identifier: NCT00678392; available at http:// clinicaltrials.gov/show/NCT00678392).

Study assessments. Safety and efficacy assessments have been published (Rini et al, 2011; Motzer et al, 2013b). Briefly, tumour assessments were performed at baseline (as close as possible to the first day of study treatment), week 6 , week 12 , and every 8 weeks thereafter. A sum of the longest diameters (SLD) for all target lesions was calculated and reported as baseline SLD (Therasse et al, 2000). Safety was assessed throughout the study period, and severity of adverse events (AEs) was graded according to Common Terminology Criteria for Adverse Events version 3.0 (Trotti et al, 2003).

Statistical analyses. Efficacy was assessed in the intention-to-treat population. Safety was assessed in all patients who received at least one dose of study drug. The primary end point of the study (PFS assessed by independent radiology review committee) and secondary end points, including OS, objective response rate, safety, and patient-reported outcomes, were previously reported (Rini et al, 2011; Cella et al, 2013; Motzer et al, 2013b).

Post hoc analyses by subgroups. In post hoc analyses, which are reported here, axitinib- and sorafenib-treated patients were first grouped by (1) type of prior therapy (sunitinib or cytokines), and then (2) response to prior therapy per RECIST v1.0 (yes (complete or partial response) $v s$ no (stable or progressive disease)), (3) duration of prior therapy ( $<v s \geqslant$ median), and (4) tumour burden (baseline SLD $<v s \geqslant$ median). Progreesion-free survival and OS were summarised using Kaplan-Meier methods. Twosided unstratified log-rank tests were used to compare PFS and OS between these subgroups. $P$-values were not adjusted for multiple comparisons and are considered exploratory. In addition, safety (grade $\geqslant 3$ treatment-related AEs) and treatment exposure were compared between patients who had received prior sunitinib or cytokines $<$ median $v s \geqslant$ median duration. The data cutoff date for these analyses was 1 November 2011.

\section{RESULTS}

\section{Efficacy}

Type of prior therapy. Of patients randomised to the axitinib $(n=361)$ or sorafenib $(n=362)$ arm, respectively, 194 (54\%) vs 195 (54\%) had previously received sunitinib, whereas 126 (35\%) vs 125 (35\%) had previously received cytokines (Rini et al, 2011). As reported by Motzer et al (2013b), patients who received prior sunitinib or cytokines had longer median investigatorassessed PFS but similar median OS with axitinib vs sorafenib treatment. Similar PFS and OS results in prior therapy groups were observed by stratified and unstratified analyses (data not shown). From initiation of sunitinib treatment, median OS (95\% confidence interval (CI)) was 33.7 months (28.6-36.9) in the axitinib arm vs 33.6 months $(30.1-37.4)$ in the sorafenib arm (adjusted hazard ratio (HR) 1.019, 95\% CI: 0.798-1.301; one-sided $P=0.560$ ). From the start of cytokine treatment, median OS (95\% CI) was 62.2 months (43.6-86.1) in the axitinib arm vs 55.8 months (35.0-212.1) in the sorafenib arm (adjusted HR 0.810, 95\% CI: $0.553-1.186$; one-sided $P=0.139)$.

Response to prior therapy. When patients were grouped according to objective response to prior sunitinib or cytokine treatment, that is, complete or partial response $v s$ stable or progressive disease, there were no statistically significant differences in PFS or OS in responders $v s$ non-responders treated with second-line axitinib or sorafenib (Table 1).

Duration of prior therapy. Median prior treatment duration was 9.7 months with sunitinib and 6.5 months with cytokines. When grouped by duration of prior treatment, that is, shorter ( $<$ median) vs longer $(\geqslant$ median) duration, PFS was significantly longer with second-line axitinib in patients who had received a longer duration of prior cytokines but not those who had received a longer duration of prior sunitinib (Table 2). The length of prior treatment did not influence PFS with second-line sorafenib. In contrast, OS with second-line axitinib or sorafenib was significantly longer in patients who received longer prior therapy, except in those treated with sunitinib followed by axitinib (Table 2; Figure 1).

Tumour burden. Median baseline SLD before second-line therapy was $98 \mathrm{~mm}$ and $101.5 \mathrm{~mm}$ in patients who had previously received sunitinib and cytokines, respectively. Patients with smaller tumour burden (baseline SLD < median) following previous treatment 


\begin{tabular}{|c|c|c|c|c|}
\hline & \multicolumn{2}{|c|}{ Prior sunitinib } & \multicolumn{2}{|c|}{ Prior cytokines } \\
\hline & Responder & Non-responder & Responder & Non-responder \\
\hline \multicolumn{5}{|l|}{ Axitinib arm } \\
\hline Patients, ${ }^{a} n$ & 47 & 145 & 13 & 113 \\
\hline mPFS, mo $(95 \% \mathrm{Cl})$ & $4.8(4.5-7.8)$ & $6.7(6.0-8.3)$ & 15.7 (12.0-NE) & $12.0(10.1-14.1)$ \\
\hline $\begin{array}{l}\mathrm{HR}^{\mathrm{b}}(95 \% \mathrm{Cl}) \\
P \text {-value }\end{array}$ & \multicolumn{2}{|c|}{$\begin{array}{c}1.131(0.791-1.617) \\
0.506\end{array}$} & \multicolumn{2}{|c|}{$\begin{array}{c}0.559(0.243-1.288) \\
0.165\end{array}$} \\
\hline mOS, mo $(95 \% \mathrm{Cl})$ & $15.7(11.2-22.6)$ & $14.8(11.8-18.5)$ & NE (22.5-NE) & 29.4 (24.2-NE) \\
\hline $\begin{array}{l}\mathrm{HR}^{\mathrm{b}}(95 \% \mathrm{Cl}) \\
P \text {-value }\end{array}$ & \multicolumn{2}{|c|}{$\begin{array}{c}1.012(0.684-1.499) \\
0.951\end{array}$} & \multicolumn{2}{|c|}{$\begin{array}{c}0.657(0.236-1.826) \\
0.415\end{array}$} \\
\hline \multicolumn{5}{|l|}{ Sorafenib arm } \\
\hline Patients, $n$ & 52 & 143 & 14 & 111 \\
\hline mPFS, mo $(95 \% \mathrm{Cl})$ & $6.5(2.9-8.3)$ & $3.5(2.9-4.7)$ & $6.9(2.8-14.0)$ & $8.2(6.7-9.9)$ \\
\hline $\begin{array}{l}\mathrm{HR}^{\mathrm{b}}(95 \% \mathrm{Cl}) \\
P \text {-value }\end{array}$ & \multicolumn{2}{|c|}{$\begin{array}{c}0.711(0.485-1.042) \\
0.080\end{array}$} & \multicolumn{2}{|c|}{$\begin{array}{c}1.313(0.716-2.410) \\
0.376\end{array}$} \\
\hline mOS, mo $(95 \% \mathrm{Cl})$ & $19.0(13.7-25.0)$ & $15.2(12.2-18.9)$ & $20.6(11.7-N E)$ & $27.8(23.1-34.5)$ \\
\hline $\begin{array}{l}\mathrm{HR}^{\mathrm{b}}(95 \% \mathrm{Cl}) \\
P \text {-value }\end{array}$ & \multicolumn{2}{|c|}{$\begin{array}{c}0.740(0.494-1.109) \\
0.143\end{array}$} & \multicolumn{2}{|c|}{$\begin{array}{c}1.451(0.685-3.072) \\
0.328\end{array}$} \\
\hline
\end{tabular}

Table 2. Efficacy by duration of prior therapy

\section{Prior sunitinib}

\section{Prior cytokines}

\begin{tabular}{|c|c|c|c|c|}
\hline & $<9.7 \mathrm{mo}$ & $\geqslant 9.7 \mathrm{mo}$ & $<6.5 \mathrm{mo}$ & $\geqslant 6.5 \mathrm{mo}$ \\
\hline
\end{tabular}

\section{Axitinib arm}

\begin{tabular}{|c|c|c|c|c|}
\hline Patients, ${ }^{a} n$ & 96 & 96 & 66 & 60 \\
\hline mPFS, mo $(95 \% \mathrm{Cl})$ & $6.4(4.6-8.3)$ & $6.6(5.2-8.3)$ & $8.6(6.5-13.8)$ & $15.7(12.2-22.1)$ \\
\hline $\begin{array}{l}\operatorname{HR}^{\mathbf{b}}(95 \% \mathrm{Cl}) \\
P \text {-value }\end{array}$ & \multicolumn{2}{|c|}{$\begin{array}{c}0.998(0.726-1.371) \\
0.996\end{array}$} & \multicolumn{2}{|c|}{$\begin{array}{c}1.966(1.265-3.058) \\
0.002\end{array}$} \\
\hline mOS, mo $(95 \% \mathrm{Cl})$ & $11.7(9.3-15.2)$ & $18.1(14.8-23.0)$ & $26.3(18.8-31.6)$ & NE (28.0-NE) \\
\hline $\begin{array}{l}\mathrm{HR}^{\mathrm{b}}(95 \% \mathrm{Cl}) \\
P \text {-value }\end{array}$ & \multicolumn{2}{|c|}{$\begin{array}{c}1.242(0.879-1.754) \\
0.220\end{array}$} & \multicolumn{2}{|c|}{$\begin{array}{c}1.983(1.115-3.525) \\
0.017\end{array}$} \\
\hline \multicolumn{5}{|l|}{ Sorafenib arm } \\
\hline Patients, ${ }^{d} n$ & 95 & 99 & 59 & 66 \\
\hline mPFS, mo $(95 \% \mathrm{Cl})$ & $3.5(1.9-4.7)$ & $4.5(3.0-6.5)$ & $6.7(5.6-9.5)$ & $8.4(7.2-10.2)$ \\
\hline $\begin{array}{l}\mathrm{HR}^{\mathrm{b}}(95 \% \mathrm{Cl}) \\
P \text {-value }\end{array}$ & \multicolumn{2}{|c|}{$\begin{array}{c}1.146(0.824-1.593) \\
0.431\end{array}$} & \multicolumn{2}{|c|}{$\begin{array}{c}1.118(0.747-1.675) \\
0.580\end{array}$} \\
\hline $\mathrm{mOS}, \mathrm{mo}(95 \% \mathrm{Cl})$ & 14.9 (10.5-18.0) & 19.0 (15.0-23.9) & $23.1(17.3-31.9)$ & $34.5(27.8-34.5)$ \\
\hline $\begin{array}{l}\operatorname{HR}^{b}(95 \% \mathrm{Cl}) \\
P \text {-value }\end{array}$ & \multicolumn{2}{|c|}{$\begin{array}{c}1.517(1.073-2.416) \\
0.018\end{array}$} & \multicolumn{2}{|c|}{$\begin{array}{c}1.930(1.133-3.289) \\
0.014\end{array}$} \\
\hline
\end{tabular}

Abbreviations: $\mathrm{Cl}=$ confidence interval; $\mathrm{HR}=$ hazard ratio; $\mathrm{mo}=$ months; $\mathrm{mOS}=$ median overall survival; $\mathrm{mPFS}=$ median progression-free survival; $\mathrm{NE}=$ not estimable

${ }^{a}$ Two patients were missing duration of prior sunitinib because of protocol deviation.

b Assuming proportional hazards model, a $H R<1$ indicates a reduction in favour of $<$ median; a HR $>1$ indicates a reduction in favour of $\geqslant$ median.

${ }^{c} P$-value based on two-sided unstratified log-rank test and not adjusted for multiplicity.

d One patient who received prior sunitinib was excluded from analysis because of missing start date. 


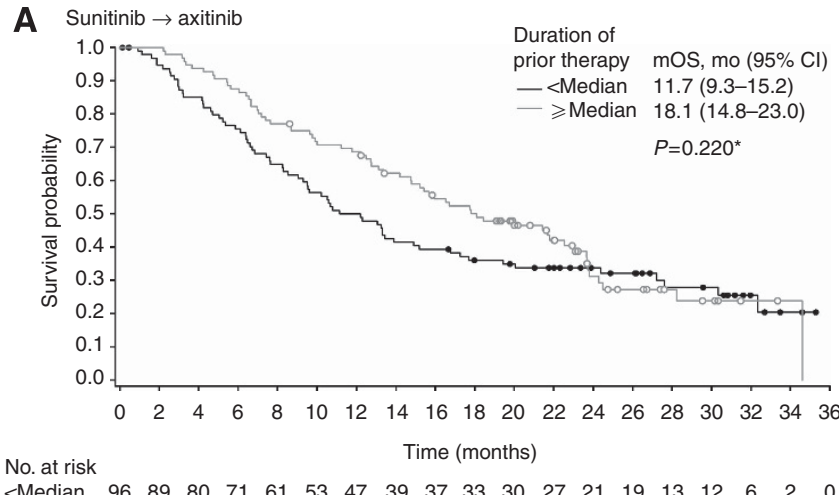

<Median $96 \begin{array}{llllllllllllllllllll}89 & 80 & 71 & 61 & 53 & 47 & 39 & 37 & 33 & 30 & 27 & 21 & 19 & 13 & 12 & 6 & 2 & 0\end{array}$ 》Median $96 \begin{array}{llllllllllllllllll}96 & 90 & 84 & 74 & 68 & 65 & 57 & 49 & 45 & 36 & 28 & 16 & 12 & 8 & 6 & 3 & 2 & 0\end{array}$

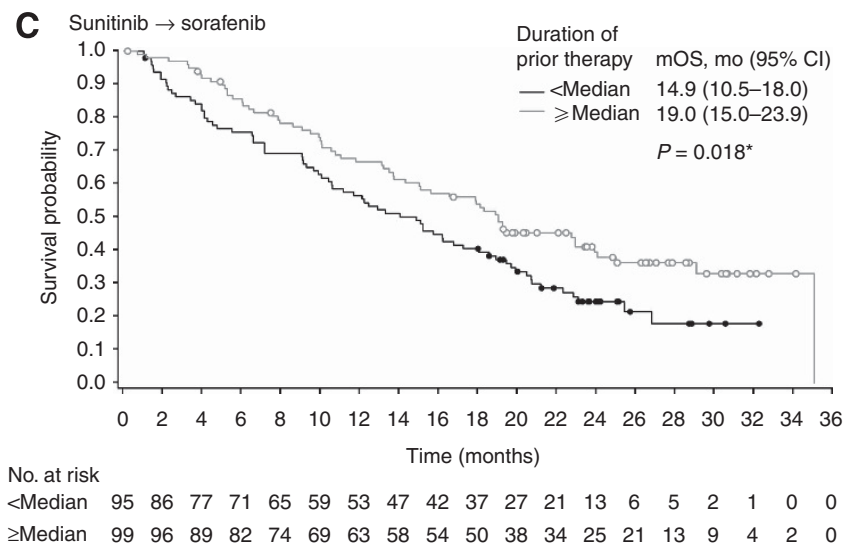

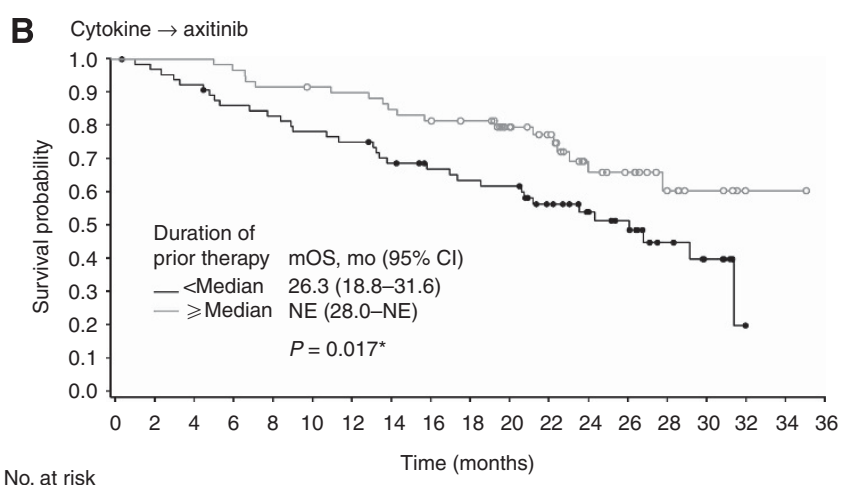

$<$ Median $66 \begin{array}{lllllllllllllllllll}64 & 60 & 55 & 53 & 50 & 48 & 43 & 40 & 37 & 36 & 29 & 23 & 18 & 10 & 8 & 1 & 0 & 0\end{array}$ $\begin{array}{llllllllllllllllllll}\geq \text { Median } & 60 & 60 & 60 & 59 & 55 & 54 & 53 & 51 & 48 & 46 & 38 & 33 & 21 & 18 & 11 & 7 & 3 & 1 & 0\end{array}$

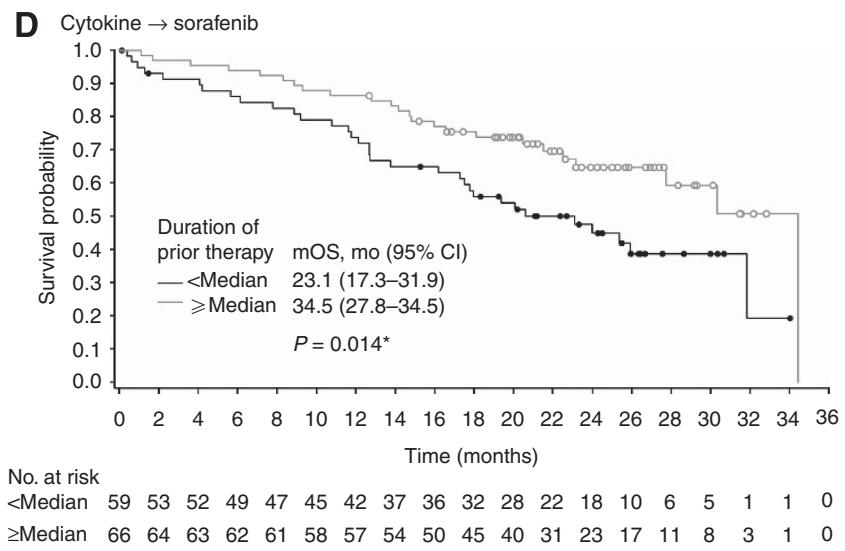

Figure 1. Kaplan-Meier estimates of overall survival with second-line (A and $\mathbf{B})$ axitinib or $(\mathbf{C}$ and $\mathbf{D})$ sorafenib by duration of prior therapy with $(\mathbf{A}$ and $\mathbf{C})$ sunitinib or (B and $\mathbf{D})$ cytokines. ${ }^{*} P$-value based on two-sided unstratified log-rank test and not adjusted for multiplicity. Abbreviations: $\mathrm{Cl}=$ confidence interval; $\mathrm{mo}=$ months; $\mathrm{mOS}=$ median overall survival; $\mathrm{NE}=$ not estimable.

with sunitinib had longer PFS with second-line sorafenib than those with larger tumour burden (baseline SLD $\geqslant$ median); in other subgroups, PFS was not significantly different in patients with smaller vs larger tumour burden (Table 3). Overall survival with second-line axitinib or sorafenib was significantly longer in patients with smaller $v s$ larger tumour burden, except in those treated with the cytokine-to-axitinib sequence (Table 3; Figure 2).

\section{Safety and treatment exposure}

Type of prior therapy. Patients who received prior cytokines had a higher incidence ( $\geqslant 5 \%$ difference) of grade $\geqslant 3$ hypertension with second-line axitinib or sorafenib than those who received prior sunitinib (Table 4). In sorafenib-treated patients, grade $\geqslant 3$ handfoot syndrome and increased lipase were also more frequently reported in the prior cytokine group.

Duration of prior therapy. In patients administered sunitinib for a longer $v s$ shorter duration, there was an increased incidence of grade $\geqslant 3$ diarrhoea with second-line axitinib treatment (Table 4). In both arms, grade $\geqslant 3$ hand-foot syndrome was more frequently reported in patients who had received shorter prior sunitinib treatment.

Patients who had received prior cytokines for longer $v s$ shorter duration had a higher incidence of grade $\geqslant 3$ hypertension when treated with second-line axitinib or sorafenib (Table 4). Grade $\geqslant 3$ increased lipase was also more common in the longer-duration cytokine subgroup of the sorafenib arm.

Patients with longer duration of prior treatment with sunitinib or cytokines were subsequently administered axitinib or sorafenib for a longer period (Table 5). Patients with longer vs shorter duration of prior sunitinib had more axitinib dose interruptions and fewer dose increases; however, the percentage of patients with dose interruptions due to AEs was similar (57.3\% vs 58.3\%, respectively). Patients with longer $v s$ shorter duration of cytokine treatment had more axitinib dose interruptions and reductions, and more patients had interruptions due to AEs (68.3\% vs 53.0\%, respectively). Similar numbers of patients in prior therapy duration subgroups had sorafenib dose interruptions and reductions.

\section{DISCUSSION}

The AXIS trial was the first phase III head-to-head study of two active VEGF-targeted agents for mRCC, and demonstrated a PFS advantage with axitinib compared with sorafenib in previously treated patients (Rini et al, 2011; Motzer et al, 2013b). Because the study did not limit enrolment by type of prior therapy - that is, sunitinib, bevacizumab plus interferon-alfa, temsirolimus, or cytokine treatment - the patient population reflected real-world treatment patterns at the time of trial initiation. The trial design, wherein patients were stratified by prior therapy before randomisation, allowed for direct comparison of prior therapy groups, noting small sample sizes and varying population totals due to global treatment trends, as well as examination of prior therapy features (response to and duration of treatment and post-treatment tumour burden). The aim of the present post hoc analysis was to help guide clinicians on the efficacy and safety profile of sequential therapies based on the initial treatment choice.

Response to prior sunitinib or cytokine therapy was not associated with longer PFS or OS in patients administered 


\begin{tabular}{|c|c|c|c|c|}
\hline & \multicolumn{2}{|c|}{ Prior sunitinib } & \multicolumn{2}{|c|}{ Prior cytokines } \\
\hline & $<98 \mathrm{~mm}$ & $\geqslant 98 \mathrm{~mm}$ & $<101.5 \mathrm{~mm}$ & $\geqslant 101.5 \mathrm{~mm}$ \\
\hline \multicolumn{5}{|l|}{ Axitinib arm } \\
\hline Patients, ${ }^{a} n$ & 89 & 101 & 62 & 64 \\
\hline mPFS, mo $(95 \% \mathrm{Cl})$ & $8.3(6.4-10.4)$ & $6.0(4.6-6.6)$ & $12.0(8.7-15.7)$ & $13.6(10.1-16.6)$ \\
\hline $\begin{array}{l}\operatorname{HR}^{\mathbf{b}}(95 \% \mathrm{Cl}) \\
P \text {-value }\end{array}$ & \multicolumn{2}{|c|}{$\begin{array}{c}0.732(0.532-1.008) \\
0.055\end{array}$} & \multicolumn{2}{|c|}{$\begin{array}{c}0.901(0.584-1.390) \\
0.631\end{array}$} \\
\hline $\mathrm{mOS}, \mathrm{mo}(95 \% \mathrm{Cl})$ & $23.8(20.0-30.4)$ & $9.8(8.3-13.1)$ & NE (24.5-NE) & 28.0 (18.8-NE) \\
\hline $\begin{array}{l}\mathrm{HR}^{\mathbf{b}}(95 \% \mathrm{Cl}) \\
P \text {-value }\end{array}$ & \multicolumn{2}{|c|}{$\begin{array}{c}0.420(0.293-0.603) \\
<0.001\end{array}$} & \multicolumn{2}{|c|}{$\begin{array}{c}0.585(0.334-1.024) \\
0.057\end{array}$} \\
\hline \multicolumn{5}{|l|}{ Sorafenib arm } \\
\hline Patients, $n$ & 99 & 90 & 62 & 61 \\
\hline mPFS, mo $(95 \% \mathrm{Cl})$ & $4.7(2.9-6.7)$ & $3.7(2.8-4.6)$ & $6.7(6.4-8.6)$ & $8.8(6.7-10.2)$ \\
\hline $\begin{array}{l}\mathrm{HR}^{\mathbf{b}}(95 \% \mathrm{Cl}) \\
P \text {-value }\end{array}$ & \multicolumn{2}{|c|}{$\begin{array}{c}0.612(0.438-0.857) \\
0.004\end{array}$} & \multicolumn{2}{|c|}{$\begin{array}{c}1.009(0.676-1.506) \\
0.975\end{array}$} \\
\hline $\mathrm{mOS}, \mathrm{mo}(95 \% \mathrm{Cl})$ & $23.9(19.9-35.0)$ & $10.0(7.5-12.1)$ & $34.5(26.0-34.5)$ & $21.6(16.6-31.9)$ \\
\hline $\begin{array}{l}\mathrm{HR}^{\mathbf{b}}(95 \% \mathrm{Cl}) \\
P \text {-value }\end{array}$ & \multicolumn{2}{|c|}{$\begin{array}{c}0.307(0.214-0.440) \\
<0.001\end{array}$} & \multicolumn{2}{|c|}{$\begin{array}{c}0.521(0.302-0.900) \\
0.017\end{array}$} \\
\hline \multicolumn{5}{|c|}{$\begin{array}{l}\text { Abbreviations: } \mathrm{Cl}=\text { confidence interval; } \mathrm{HR}=\text { hazard ratio; } \mathrm{mo}=\text { months; } \mathrm{mOS}=\text { median overall survival; } \mathrm{mPFS}=\text { median progression-free survival; } \\
\text { longest diameters. } \\
\mathrm{a}_{\text {a }} \text { Two patients who received prior sunitinib were excluded from analysis due to protocol deviation. } \\
{ }^{\mathrm{b}} \text { Assuming proportional hazards model, a } \mathrm{HR}<1 \text { indicates a reduction in favour of }<\text { median; a } \mathrm{HR}>1 \text { indicates a reduction in favour of } \geqslant \text { median. } \\
{ }^{\mathrm{c}} \mathrm{P} \text {-value based on two-sided unstratified log-rank test and not adjusted for multiplicity. }\end{array}$} \\
\hline
\end{tabular}

second-line axitinib or sorafenib. Similar to these findings, a retrospective analysis of an international database of 464 patients with $\mathrm{mRCC}$ also found no correlation between response to firstline and second-line VEGF-targeted therapy (Al-Marrawi et al, 2013). Together, these data suggest that lack of response to a VEGF-targeted agent in the first-line setting does not preclude positive clinical outcomes with a second-line VEGF-targeted agent, which is consistent with RCC being predominantly a VEGF-driven disease. However, it should be noted that response to a particular therapy appears to influence survival with that therapy. In a pooled, retrospective analysis of patients with mRCC treated with sunitinib, interferon-alfa, axitinib, sorafenib, temsirolimus, or temsirolimus plus interferon-alfa in phase II or III clinical trials, the degree of tumour shrinkage correlated with OS, and maximal tumour shrinkage $(-100 \%$ to $-60 \%)$ was an independent predictor of OS (Grünwald et al, 2013).

In contrast, longer prior treatment with sunitinib or cytokines was generally associated with longer OS with second-line axitinib or sorafenib. This may, at least in part, reflect underlying tumour biology, that is, patients with slower growing tumours would be expected to be able to remain on sunitinib or cytokines for a longer period and to survive longer with subsequent therapy. Prior treatment duration may approximate PFS on prior therapy, as eligibility criteria for the AXIS trial included RECIST-defined progressive disease (Therasse et al, 2000) after one previous therapy. Consistent with our results, another retrospective study of 119 patients with mRCC showed that PFS $>6$ months with a prior VEGF receptor tyrosine kinase inhibitor (sunitinib, sorafenib, or axitinib) was a prognostic factor for longer OS with a second-line VEGF receptor tyrosine kinase inhibitor or mTOR inhibitor (Seidel et al, 2012). The relationship between prior treatment duration and PFS with second-line axitinib or sorafenib was less clear; significantly longer PFS was only observed in patients treated with axitinib who previously received cytokine therapy for a longer $v s$ shorter duration. This may reflect higher potency of axitinib compared with sorafenib in patients with slower progressing disease. Similar to the results reported here for patients treated with sunitinib followed by axitinib or sorafenib, an association between PFS during first-line and second-line VEGF-targeted therapy was not observed in the retrospective database analysis of patients with mRCC (Al-Marrawi et al, 2013).

In addition, smaller tumour burden following treatment with sunitinib or cytokines was associated with longer OS with either second-line axitinib or sorafenib. Longer PFS was also seen in patients who had smaller $v s$ larger tumour burden following sunitinib therapy, but reached significance only in the sorafenib arm. Other retrospective studies have identified a correlation between tumour burden and survival in previously treated patients with mRCC. An analysis of patients who were treated in the phase III TARGET trial or a phase II trial of continuous sunitinib dosing following prior cytokine therapy identified smaller baseline tumour burden as a prognostic factor for longer PFS and OS (Iacovelli et al, 2012). In a retrospective evaluation of 69 patients with mRCC and median baseline total tumour burden of $14 \mathrm{~cm}, 50$ (73\%) of whom had received prior systemic therapy (cytokines or targeted agents), there was a significant correlation between total baseline tumour burden $\leqslant 13 \mathrm{~cm}$ and PFS during treatment with sunitinib (Basappa et al, 2011). In addition, baseline SLD following treatment with sunitinib and/or sorafenib was identified as a predictive factor for OS in patients treated with everolimus in the phase III RECORD-1 trial (Stein et al, 2012). Results reported here and in other studies suggest that patients with a lower initial tumour burden are likely to take longer to reach a lethal tumour burden and may reflect slower-growing disease; however, these data do not assist in selection of a particular agent for second-line or subsequent targeted therapy based on this characteristic.

As has been previously reported for this study (Motzer et al, 2013b), patients previously treated with cytokines had longer PFS 


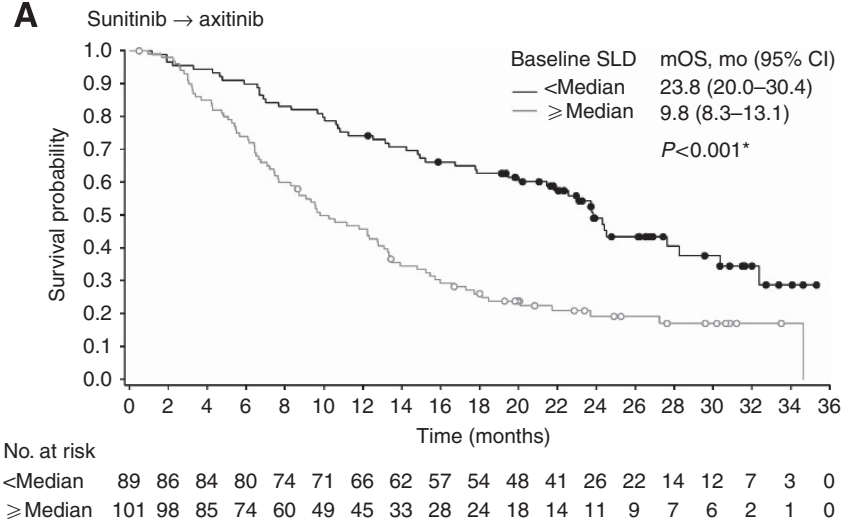

C Sunitinib $\rightarrow$ sorafenib

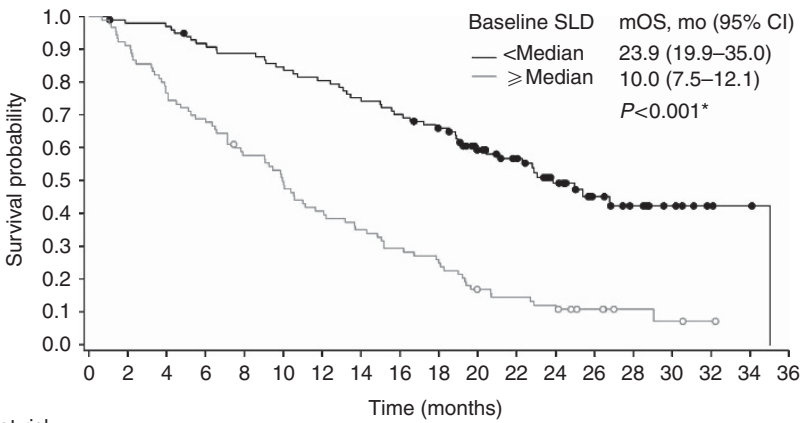

$\begin{array}{llllllllllllllllllll}\text { <Median } & 99 & 96 & 95 & 89 & 86 & 82 & 78 & 72 & 68 & 62 & 49 & 41 & 29 & 18 & 12 & 7 & 3 & 2 & 0\end{array}$

$\begin{array}{llllllllllllllllllll}\text { Median } & 90 & 82 & 69 & 62 & 51 & 44 & 36 & 31 & 26 & 23 & 14 & 12 & 10 & 6 & 3 & 2 & 1 & 0 & 0\end{array}$
B

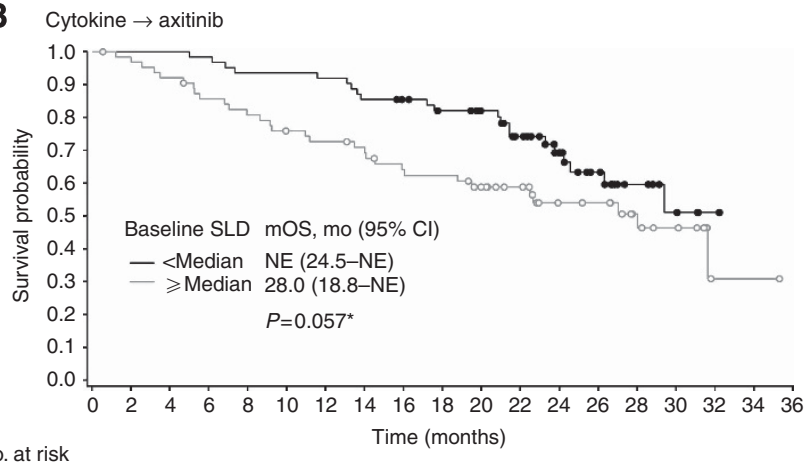

<Median $62 \begin{array}{llllllllllllllllll}62 & 62 & 61 & 58 & 58 & 57 & 53 & 51 & 47 & 43 & 35 & 25 & 18 & 10 & 6 & 3 & 0 & 0\end{array}$

》Median $64 \begin{array}{lllllllllllllllllll}62 & 58 & 53 & 50 & 46 & 44 & 41 & 37 & 36 & 31 & 27 & 19 & 18 & 11 & 9 & 1 & 1 & 0\end{array}$

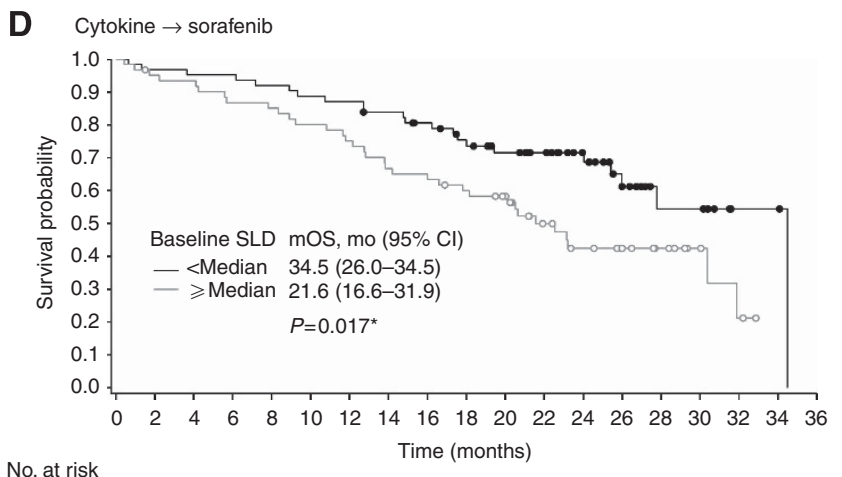

<Median $62 \begin{array}{llllllllllllllllll}60 & 59 & 59 & 57 & 55 & 54 & 51 & 47 & 42 & 36 & 32 & 25 & 15 & 8 & 8 & 2 & 2 & 0\end{array}$

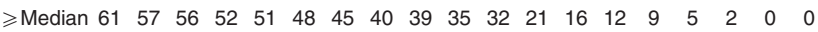

Figure 2. Kaplan-Meier estimates of overall survival with second-line (A and B) axitinib or (C and $\mathbf{D})$ sorafenib by baseline SLD following prior therapy with $(\mathbf{A}$ and $\mathbf{C})$ sunitinib or (B and $\mathbf{D})$ cytokines. ${ }^{*} P$-value based on two-sided unstratified log-rank test and not adjusted for multiplicity. Abbreviations: $\mathrm{Cl}=$ confidence interval; $\mathrm{mo}=$ months; $\mathrm{mOS}=$ median overall survival; $\mathrm{NE}=$ not estimable; $\mathrm{SLD}=$ sum of the longest diameters.

Table 4. Treatment-related grade $\geqslant 3$ adverse events ${ }^{\mathrm{a}}$ by duration and type of prior therapy

\begin{tabular}{|c|c|c|c|c|c|c|}
\hline & \multicolumn{3}{|c|}{ Prior sunitinib, $n(\%)$} & \multicolumn{3}{|c|}{ Prior cytokines, n (\%) } \\
\hline & $<9.7 \mathrm{mo}$ & $\geqslant 9.7 \mathrm{mo}$ & Total & $<6.5 \mathrm{mo}$ & $\geqslant 6.5 \mathrm{mo}$ & Total \\
\hline \multicolumn{7}{|l|}{ Axitinib arm } \\
\hline $\begin{array}{l}\text { Patients, } n \\
\text { Diarrhoea } \\
\text { Hypertension } \\
\text { Fatigue } \\
\text { Hand-foot syndrome } \\
\text { Lipase increased }\end{array}$ & $\begin{array}{c}96 \\
10(10.4) \\
10(10.4) \\
8(8.3) \\
8(8.3) \\
0\end{array}$ & $\begin{array}{c}94 \\
16(17.0) \\
10(10.6) \\
10(10.6) \\
3(3.2) \\
0\end{array}$ & $\begin{array}{c}190 \\
26(13.7) \\
20(10.5) \\
18(9.5) \\
11(5.8) \\
0\end{array}$ & $\begin{array}{c}66 \\
5(7.6) \\
15(22.7) \\
8(12.1) \\
3(4.5) \\
1(1.5)\end{array}$ & $\begin{aligned} & 60 \\
& 7(11.7) \\
& 17(28.3) \\
& 8(13.3) \\
& 3(5.0) \\
& 2(3.3)\end{aligned}$ & $\begin{array}{c}126 \\
12(9.5) \\
32(25.4) \\
16(12.7) \\
6(4.8) \\
3(2.4)\end{array}$ \\
\hline \multicolumn{7}{|l|}{ Sorafenib arm } \\
\hline $\begin{array}{l}\text { Patients, } n \\
\text { Diarrhoea } \\
\text { Hypertension } \\
\text { Fatigue } \\
\text { Hand-foot syndrome } \\
\text { Lipase increased }\end{array}$ & $\begin{aligned} & 93 \\
& 6(6.5) \\
& 10(10.8) \\
& 5(5.4) \\
& 14(15.1) \\
& 1(1.1)\end{aligned}$ & $\begin{array}{c}96 \\
10(10.4) \\
8(8.3) \\
3(3.1) \\
6(6.3) \\
2(2.1)\end{array}$ & $\begin{array}{c}189 \\
16(8.5) \\
18(9.5) \\
8(4.2) \\
20(10.6) \\
3(1.6)\end{array}$ & $\begin{aligned} & 58 \\
5 & (8.6) \\
7 & (12.1) \\
3 & (5.2) \\
11 & (19.0) \\
& 2(3.4)\end{aligned}$ & $\begin{aligned} & 65 \\
5 & (7.7) \\
14 & (21.5) \\
1 & (1.5) \\
14 & (21.5) \\
& 7(10.8)\end{aligned}$ & $\begin{aligned} & 123 \\
10 & (8.1) \\
21 & (17.1) \\
4 & (3.3) \\
25 & (20.3) \\
9 & (7.3)\end{aligned}$ \\
\hline
\end{tabular}

and OS with axitinib or sorafenib than those previously treated with sunitinib. Consistent with those findings, median OS from start of prior treatment was nearly twice as long in patients previously treated with cytokines $v s$ sunitinib. The shorter median duration of prior cytokines $v s$ sunitinib may have resulted in a 'lead-time bias'; moreover, patients in the sunitinib group may have developed resistance to VEGF receptor inhibitors during prior therapy, resulting in diminished efficacy with second-line axitinib or sorafenib (Motzer et al, 2013b). In addition, patients who were previously treated with cytokines for long periods 


\begin{tabular}{|c|c|c|c|c|}
\hline & \multicolumn{2}{|c|}{ Prior sunitinib } & \multicolumn{2}{|c|}{ Prior cytokines } \\
\hline & $<9.7 \mathrm{mo}$ & $\geqslant 9.7 \mathrm{mo}$ & $<6.5 \mathrm{mo}$ & $\geqslant 6.5 \mathrm{mo}$ \\
\hline \multicolumn{5}{|l|}{ Axitinib arm } \\
\hline $\begin{array}{l}\text { Patients, }{ }^{a} n \\
\text { Days on drug, median (range) } \\
\text { Median relative dose intensity, }{ }^{\mathbf{b}} \% \\
\text { Dose increase, } n(\%) \\
\text { Dose interruption, } n(\%) \\
\text { Dose reduction, } n(\%)\end{array}$ & $\begin{array}{c}96 \\
178(1-955) \\
98.8 \\
41(42.7) \\
68(70.8) \\
31(32.3)\end{array}$ & $\begin{array}{c}96 \\
197(5-953) \\
97.1 \\
31(32.3) \\
79(82.3) \\
34(35.4)\end{array}$ & $\begin{array}{c}66 \\
294(17-945) \\
99.4 \\
25(37.9) \\
47(71.2) \\
18(27.3)\end{array}$ & $\begin{array}{c}60 \\
514(3-945) \\
94.7 \\
26(43.3) \\
51(85.0) \\
29(48.3)\end{array}$ \\
\hline \multicolumn{5}{|l|}{ Sorafenib arm } \\
\hline $\begin{array}{l}\text { Patients, }{ }^{a} n \\
\text { Days on drug, median (range) } \\
\text { Median relative dose intensity, }{ }^{\text {b }} \% \\
\text { Dose interruption, } n(\%) \\
\text { Dose reduction, } n(\%)\end{array}$ & $\begin{array}{c}93 \\
93(11-743) \\
92.7 \\
72(77.4) \\
43(46.2)\end{array}$ & $\begin{array}{c}96 \\
120(4-931) \\
94.7 \\
69(71.9) \\
43(44.8)\end{array}$ & $\begin{array}{c}58 \\
240(8-1037) \\
90.7 \\
46(79.3) \\
35(60.3)\end{array}$ & $\begin{array}{c}65 \\
295(11-977) \\
89.8 \\
49(75.4) \\
42(64.6)\end{array}$ \\
\hline
\end{tabular}

without disease progression may have had inherently lessaggressive disease than those previously treated with sunitinib. As a result, different prognostic factors between the prior cytokine and prior sunitinib groups may partially account for differences in OS from the start of previous therapy.

Several distinctions emerged in the toxicity profiles of second-line treatment with axitinib and sorafenib in patients who had received prior sunitinib $v s$ cytokines, and may, in part, reflect sequential use of therapies with similar $v s$ different mechanisms of action. Class effects of VEGF pathway-targeted agents include hypertension, fatigue, asthenia, diarrhoea, nausea, anorexia, hand-foot syndrome, and rash (Cohen and Oudard, 2012). More frequent reports of grade $\geqslant 3$ hypertension in patients who had received prior cytokines may be due to management of this toxicity during prior therapy in patients who had received sunitinib. There is also a possibility that patients who developed hypertension while receiving prior sunitinib were excluded from the AXIS trial, as blood pressure $\leqslant 140$ / $90 \mathrm{~mm} \mathrm{Hg}$ was required for study entry (Motzer et al, 2013b). The higher incidence of grade $\geqslant 3$ hypertension (and hand-foot syndrome in the sorafenib arm) in patients who received prior cytokines could also be attributed to these patients remaining on treatment in the AXIS trial longer than those who received prior sunitinib; this would be expected to increase the likelihood of experiencing these AEs. The overall toxicity profile of sorafenib in patients previously treated with sunitinib and cytokines, respectively, was consistent with that observed in the INTORSECT (Hutson et al, 2013) and TARGET (Escudier et al, 2007) trials; however, the incidence of grade $\geqslant 3$ hypertension, hand-foot syndrome, and diarrhoea in patients previously treated with cytokines was higher in the AXIS study than in the TARGET trial. The safety profile of second-line axitinib and sorafenib differed modestly by duration of prior therapy. The higher incidence of grade $\geqslant 3$ diarrhoea in axitinib-treated patients who had received longer prior sunitinib therapy suggests that some toxicities associated with VEGF pathway-targeted agents may accrue when these drugs are administered successively. In contrast, patients who had received shorter prior sunitinib treatment had a higher incidence of grade $\geqslant 3$ hand-foot syndrome with axitinib or sorafenib; these patients may have been less likely to experience hand-foot syndrome during prior sunitinib therapy, as they received a shorter treatment duration.
Optimising drug sequencing in patients with mRCC to extend disease control is a key area of clinical research (Gore and Larkin, 2011; Hudes et al, 2011). Data from head-to-head randomised clinical trials comparing VEGF pathway and mTOR inhibitors support the use of VEGFR tyrosine kinase inhibitors in the first-line setting (Motzer et al, 2013a) and in the second-line setting following disease progression on sunitinib (Hutson et al, 2013). However, there are currently insufficient clinical data directly comparing efficacy of different VEGF pathway-targeted agents, and so clinical decisions are based on drug toxicity profiles and patient preferences and comorbidities (Sonpavde et al, 2012). The retrospective, post hoc analyses presented here are limited by small subgroups and lack of correction for multiple comparisons; significant results should be viewed as exploratory and should be confirmed in future studies. In addition, the remaining prior therapy groups in the AXIS study represented small proportions of the trial population (bevacizumab plus interferon-alfa: $8 \%$; temsirolimus: $3 \%$ ) (Rini et al, 2011), which precluded meaningful conclusions if further divided into subgroups by objective response to prior therapy, prior therapy duration, or tumour burden. Nevertheless, the results may help to refine sequential treatment regimens for mRCC and provide insight into predictive and/or prognostic factors for efficacy of second-line antiangiogenic therapy.

In general, these data suggest that outcome to second-line therapy is better when duration of first-line treatment is longer, and that tumour burden is likely to be predictive of survival as previously suggested (Basappa et al, 2011; Iacovelli et al, 2012; Stein et al, 2012). However, for a given agent, differences in toxicity profiles by prior therapy and differences in outcome by response to prior therapy, length of prior therapy, or baseline SLD are not convincing enough to aid in selection of a second-line treatment.

\section{ACKNOWLEDGEMENTS}

This study was sponsored by Pfizer Inc. We thank Glen I Andrews, MS, of Pfizer Inc for review of the manuscript. Medical writing support was provided by Joanna Bloom, $\mathrm{PhD}$, of Engage Scientific Solutions, and was funded by Pfizer Inc. 


\section{CONFLICT OF INTEREST}

$\mathrm{BE}$ has served as an advisor for Bayer, Pfizer, and Novartis and has received honoraria from Bayer, Roche, Pfizer, Genentech, Novartis, and AVEO. MDM has served as an advisor for Pfizer, Novartis, AVEO, Genentech, and Abbott and has received research funding from GlaxoSmithKline, Genentech, Pfizer, Novartis, Eisai, Bayer, and Abbott. RJM has served as an advisor for Pfizer, Genentech, and AVEO, received research funding from Pfizer, Novartis, and GlaxoSmithKline, and provided paid expert testimony for Pfizer. TEH has served as an advisor for and received honoraria and research funding from Pfizer, Bayer, GlaxoSmithKline, Genentech, AVEO, and Novartis. JIC has served on speakers' bureaus for Pfizer, Prometheus, and Bristol-Myers Squibb and on advisory boards for Bayer. EP has served as an advisor for Pfizer, Astellas, Bayer, and Novartis and received research funding from Pfizer and GlaxoSmithKline. PZ has served as an advisor for Pfizer and Novartis. GK has served as an advisor for Pfizer. MS has served as an advisor for and received honoraria and research funding from Pfizer, Bayer, Roche, Novartis, and GlaxoSmithKline. JT, BR, LC, and $\mathrm{SH}$ are employees of Pfizer Inc and own Pfizer stock. SK, employed at Pfizer at the time of the study described here, is currently employed by Mirna Therapeutics and owns stock in Pfizer and Mirna Therapeutics. BIR has served as an advisor for and received research funding from Pfizer. HYL declares no conflict of interest.

\section{REFERENCES}

Al-Marrawi MY, Rini BI, Harshman LC, Bjarnason G, Wood L, Vaishampayan U, Mackenzie M, Knox JJ, Agarwal N, Al-Harbi H, Kollmannsberger C, Tan MH, Rha SY, Donskov FN, North S, Choueiri TK, Heng DY (2013) The association of clinical outcome to first-line VEGFtargeted therapy with clinical outcome to second-line VEGF-targeted therapy in metastatic renal cell carcinoma patients. Target Oncol 8: 203-209.

Basappa NS, Elson P, Golshayan AR, Wood L, Garcia JA, Dreicer R, Rini BI (2011) The impact of tumor burden characteristics in patients with metastatic renal cell carcinoma treated with sunitinib. Cancer 117: 1183-1189.

Cella D, Escudier B, Rini B, Chen C, Bhattacharyya H, Tarazi J, Rosbrook B, Kim S, Motzer R (2013) Patient-reported outcomes for axitinib vs sorafenib in metastatic renal cell carcinoma: phase III (AXIS) trial. Br J Cancer 108: 1571-1578.

Cohen RB, Oudard S (2012) Antiangiogenic therapy for advanced renal cell carcinoma: management of treatment-related toxicities. Invest New Drugs 30: 2066-2079.

Escudier B, Eisen T, Porta C, Patard JJ, Khoo V, Algaba F, Mulders P, Kataja V (2012) Renal cell carcinoma: ESMO Clinical Practice Guidelines for diagnosis, treatment and follow-up. Ann Oncol 23(suppl 7): vii65-vii71.

Escudier B, Eisen T, Stadler WM, Szczylik C, Oudard S, Siebels M, Negrier S, Chevreau C, Solska E, Desai AA, Rolland F, Demkow T, Hutson TE, Gore M, Freeman S, Schwartz B, Shan M, Simantov R, Bukowski RM (2007) Sorafenib in advanced clear-cell renal-cell carcinoma. N Engl J Med 356: $125-134$

Gore ME, Larkin JM (2011) Challenges and opportunities for converting renal cell carcinoma into a chronic disease with targeted therapies. Br J Cancer 104: 399-406

Grünwald V, Lin X, Kalanovic D, McKay R, Perkins J, Simantov R, Choueiri T (2013) Tumor Response is an Independent Prognostic Factor in Patients (pts) Treated for Metastatic Renal Cell Carcinoma (mRCC). In European Cancer Congress 2013. p 2702. Amsterdam: The Netherlands.

Hudes GR, Carducci MA, Choueiri TK, Esper P, Jonasch E, Kumar R, Margolin KA, Michaelson MD, Motzer RJ, Pili R, Roethke S, Srinivas S
(2011) NCCN Task Force report: optimizing treatment of advanced renal cell carcinoma with molecular targeted therapy. J Natl Compr Canc Netw 9(suppl 1): S1-S29.

Hutson TE, Escudier B, Esteban E, Bjarnason GA, Lim HY, Pittman KB, Senico P, Niethammer A, Lu DR, Hariharan S, Motzer RJ (2013) Randomized phase III trial of temsirolimus versus sorafenib as second-line therapy after sunitinib in patients with metastatic renal cell carcinoma. J Clin Oncol 32: 760-767.

Iacovelli R, Lanoy E, Albiges L, Escudier B (2012) Tumour burden is an independent prognostic factor in metastatic renal cell carcinoma. BJU Int 110: $1747-1753$.

Ljungberg B, Bensalah K, Bex A, Canfield S, Dabestani S, Hofmann F, Hora M, Kuczyk MA, Lam T, Marconi L, Merseburger AS, Mulders PFA, Staehler M, Volpe A (2013) Guidelines on Renal Cell Carcinoma: Europeon Association of Urology 2013. http://www.uroweb.org/gls/pdf/ 10_Renal_Cell_Carcinoma_LR.pdf. Accessed 20 August 2013.

Motzer RJ, Barrios CH, Kim TM, Falcon S, Cosgriff T, Harker WG, Pittman KB, Sabbatini R, Rha SY, Flaig TW, Page RD, Bavbek SE, Beck JT, Patel PM, Schiff E, Vaury A, Niolat J, Gogov S, Anak O, Knox J (2013a) Record-3: phase II randomized trial comparing sequential first-line everolimus (EVE) and second-line sunitinib (SUN) versus first-line SUN and second-line EVE in patients with metastatic renal cell carcinoma (mRCC). In ASCO Meeting Abstracts Vol. 31, p 4504. American Society of Clinical Oncology: Chicago, IL, USA.

Motzer RJ, Escudier B, Tomczak P, Hutson TE, Michaelson MD, Negrier S, Oudard S, Gore ME, Tarazi J, Hariharan S, Chen C, Rosbrook B, Kim S, Rini BI (2013b) Axitinib versus sorafenib as second-line treatment for advanced renal cell carcinoma: overall survival analysis and updated results from a randomised phase 3 trial. Lancet Oncol 14: 552-562.

National Comprehensive Cancer Network (2013) NCCN Clinical Practice Guidelines in Oncology Kidney Cancer, v.1.2013. http://www.nccn.org/ index.asp. Accessed 7 March 2013.

Rini BI, Escudier B, Tomczak P, Kaprin A, Szczylik C, Hutson TE, Michaelson MD, Gorbunova VA, Gore ME, Rusakov IG, Negrier S, Ou YC, Castellano D, Lim HY, Uemura H, Tarazi J, Cella D, Chen C, Rosbrook B, Kim S, Motzer RJ (2011) Comparative effectiveness of axitinib versus sorafenib in advanced renal cell carcinoma (AXIS): a randomised phase 3 trial. Lancet 378: 1931-1939.

Seidel C, Busch J, Weikert S, Steffens S, Fenner M, Ganser A, Grunwald V (2012) Progression free survival of first line vascular endothelial growth factor-targeted therapy is an important prognostic parameter in patients with metastatic renal cell carcinoma. Eur J Cancer 48: 1023-1030.

Sonpavde G, Choueiri TK, Escudier B, Ficarra V, Hutson TE, Mulders PF, Patard JJ, Rini BI, Staehler M, Sternberg CN, Stief CG (2012) Sequencing of agents for metastatic renal cell carcinoma: can we customize therapy? Eur Urol 61: 307-316.

Stein A, Bellmunt J, Escudier B, Kim D, Stergiopoulos SG, Mietlowski W, Motzer RJ. RECORD-1 Trial Study Group (2012) Survival prediction in everolimus-treated patients with metastatic renal cell carcinoma incorporating tumor burden response in the RECORD-1 trial. Eur Urol 64: 994-1002.

Therasse P, Arbuck SG, Eisenhauer EA, Wanders J, Kaplan RS, Rubinstein L, Verweij J, Van Glabbeke M, van Oosterom AT, Christian MC, Gwyther SG (2000) New guidelines to evaluate the response to treatment in solid tumors. European Organization for Research and Treatment of Cancer, National Cancer Institute of the United States, National Cancer Institute of Canada. J Natl Cancer Inst 92: 205-216.

Trotti A, Colevas AD, Setser A, Rusch V, Jaques D, Budach V, Langer C, Murphy B, Cumberlin R, Coleman CN, Rubin P (2003) CTCAE v3.0: development of a comprehensive grading system for the adverse effects of cancer treatment. Semin Radiat Oncol 13: 176-181.

This work is licensed under the Creative Commons License. To view a copy of this license, visit http://creativecommons.
Ay org/licenses/by-nc-sa/3.0/ 